\title{
Effects of Soil Nutrients, Enzyme Activities and Microbial Composition in Vegetable-Polygonatum Odoratum Rotation Regimes
}

\author{
YONG CHEN ${ }^{1,2}$, XIANWEN ZHANG ${ }^{3}$, YIHONG HU², CHENZHONG JIN², ZHI LIU³, \\ NAIMEI TU ${ }^{*}$, AIYU LIU ${ }^{1 *}$ \\ ${ }^{1}$ College of Agronomy, Hunan Agricultural University, Changsha 417000, China \\ ${ }^{2}$ Collaborative Innovation Center for Field Weeds Control of Hunan Province, Hunan University of Humanities, Science and \\ Technology, Changsha 417000, China \\ ${ }^{3}$ College of Bioscience and Biotechnology, Hunan Agricultural University, Changsha 410128, China
}

\begin{abstract}
The rotation regimes significantly alter soil properties, however, understanding the effect of crop rotation in various crops system was currently limited. The aim of this research was to reveal the variation in crop productivity, soil nutrients, enzyme activities, and bacterial community composition in vegetable-Polygonatum odoratum rotation horticulture. Thus, a 2-year field experiment was carried out under the P.odoratum-P.odoratum rotation $(C C)$ and vegetable-P.odoratum rotation $(F C)$ system through a randomized complete block design comprising of triplicate plots. The results showed that FC promoted most of the beneficial agronomic traits, soil nutrients, enzyme activities, and reducing root rot disease of P.odoratum. High-throughput sequencing revealed a shift in the microbial community groups with high environmental contaminants degradation ability, and a close correlation between increasing microbial diversity and major environmental factors like soil nutrients, enzyme activities under FC cropping system compared with CC. Therefore, crop rotations with vegetableP.odoratum was recommended in cultivation.
\end{abstract}

Keywords: Continuous cropping, Polygonatum odoratum, Enzyme activities, Soil nutrients, Microbial diversity

\section{Introduction}

Polygonatum belongs to the family Asparagaceae with its genus comprising of approximately 63 species and widely distributed in Europe and Asia [1]. Polygonatum odoratum, one of the species under the Asparagaceae, it has for a long time been used in traditional Chinese and Mongolian medicine for the treatment of various illnesses that range from weakness, impotence, diseases of the kidneys, gonorrhea, pains in the back and legs, coughing, tuberculosis, yellow liquorstasis, and diabetes [2]. Indeed, the extracts of P.odoratum have also been confirmed to be highly valuable in the treatment of breast cancer through its extract that have the potential of inhibiting the proliferation and induces the apoptosis of human breast cancer MDA-MB-231 cells [3]. Studies on P. odoratum have also identified higher levels of steroidal saponins, sterols, homoisoflavonoids and cholestane glycosides [2, 4-7]. Moreover, its rhizomes form a highly nutritious source of food, making it one of the most consumed members of Asparagaceae in China [1]. Despite the high economic, nutritional and aesthetic significance of $P$. odoratum, its production has continued to face soil quality degradation challenges $[8,9]$.

The property of soil was an important factor in $P$. odoratum planting. Soil is a heterogenous environment that is modelled by several biotic and abiotic components that are involved in physical, chemical, and biological activities, abiotic factors include microorganisms, small animals, and enzymes [10]. Subsequently, due to their sensitivity to environmental stress, soil biological and biochemical properties are used to evaluate soil quality [11].

*email: naimei.tu@gmail.com 
Previous studies indicated that enzyme activities act as biomarkers to assess the quality of soil due to their sensitivity to soil management practices, nutrient cycling, organic matter decomposition, and bioremediation activities [12]. Soil enzyme activities are influenced by soil organic matter content and in turn they correspond to a large proportion of soil microbial communities [13].

The sustainability of long-term agricultural productivity greatly relies on three most important factors: soil, microbial community and agricultural management practices [14]. Moreover, soil environment contributes in selection of dominant resident microbial community, which in turn reflects on the performance of crop [15]. Even though continuous cropping was a common practice in intensive horticultural production, but also cause negative effects on soil physicochemical properties and fertility, resulting decline in crop productivity [16]. Furthermore, horticultural practices like application of fertilizer and the most importantly rotation in farmed crops could alter soil properties with an ultimate impact on crop production and quality [17]. Indeed, this will vary based on crop rotation practice and the duration of the practice [18]. The vegetable- $P$. odoratum farming system was a specific and importantly rotation in horticulture system $[19,20]$. However, few researches explored the changes on soil nutrient, enzyme activity and microbial community composition in vegetableP.odoratum rotation system. Therefore, the aim of this research was to explore the variation in the soil nutrient quality, enzyme activities and microbial community composition in a vegetable-P.odoratum rotation horticulture and the effect on the crop productivity and quality.

\section{Materials and methods}

\subsection{Study site and materials}

The study plots were established in Lianyuan city, Hunan province (Coordinates: $27^{\circ} 41^{\prime} 31^{\prime \prime} \mathrm{N}$ $\left.111^{\circ} 39^{\prime} 50^{\prime \prime}\right)$, carried out a 2-year cropping system in a previously uncultivated bare land, the soil type was clay-loam soil. The two major crops used in rotation in this study were Polygonatum odoratum (Mill.) and cabbage-peas. Three treatments were designed, P.odoratum-P.odoratum rotation (CC) and vegetable-P.odoratum rotation (FC) and an uncultivated study plot (CK) was used as the control. The plots were organized in a randomized complete block design comprising of triplicate plots (1.5 meters by 20 meters) for each of the three cropping systems at the two different cropping entry points $(3 \times 3 \times 2=18$ plots $)$. Hence, each study block consisted of one crop cycles per rotation, i.e., FC: vegetable planted in the first year and P.odoratum planted in the second subsequent year. CC: P.odoratum planted in the first year and re-planted again in the second subsequent year. CK: No crop planted in the first and second subsequent year. All the study plots were amended with calcium, and fertilized with phosphorus, potassium and animal manure at the onset of the experiment, as well as routinely managed using recommended production practices to avoid overgrowth of weeds.

\subsection{Soil sampling}

Soil samples were collected in triplicates from each experimental plot just before planting of the crops, in crop flowering stage, in rhizome expansion phase and later during crop wilt phase, respectively. Soil sampling was conducted using 8 soil cores in every study plot and later, soil samples from each plot were mixed to form a composite sample. Each soil sample was passed through a 3.35$\mathrm{mm}$ sieve to eliminate rocks and large organic debris. The samples were divided into three parts and stored in sterile plastic bags that were labeled appropriately and thereafter stored at $-80{ }^{\circ} \mathrm{C}$ until further processing.

\subsection{Soil Enzymatic activity}

In this study, five enzymes were selected for analysis. They include Catalase (CAT), Urease (UE), Sucrase (SC), Polyphenol Oxidase (PPO) and Acid Phosphatase (ACP). All these enzymatic tests were conducted in triplicates for all the soil samples as previously described [21]. 


\subsection{Measurement of soil chemical properties}

Soil chemical properties including $p \mathrm{H}, \mathrm{N}, \mathrm{P}$ and $\mathrm{K}$ content were analyzed as described by Liu et al. [13]. Briefly, soil $p \mathrm{H}$ was determined in suspensions with deionized water (1:5 soil/water, w/v). Total $\mathrm{N}$ (TN) was determined by Kjeldahl methodology. Available N (AN) was estimated by the alkaline hydrolysis diffusion method. Total P (TP) and K (TK) was measured by sodium hydroxide fusion, followed by colorimetric analysis; the available $\mathrm{P}(\mathrm{AP})$ and $\mathrm{K}(\mathrm{AK})$ was extracted with $0.5 \mathrm{M} \mathrm{NaHCO} 3$ $(p \mathrm{H} 8.5)$ and quantified as described above.

\subsection{Measurement of agronomic traits}

Leaf area, leaf index, number of leaves, plant height, plant productivity and polysaccharide content were measured on ten randomly $\mathrm{P}$. odoratum plots in FC and $\mathrm{CC}$ cropping treatments. Plant productivity were determined at 3 points in each plot $\left(1.5 \mathrm{~m}^{2}\right.$ per point $)$, and the newborn rhizome was cut out and weighed. The polysaccharide percentage content was determined through Phenol-sulfuric acid spectrophotometric method.

\subsection{Measurement of root rot disease parameters}

The root rot disease parameters were measured for all treatments (FC and CC) during three stages (Seedling stage (SS), Flowering stage (FS), and Rhizome extension stage (RE)). The disease cases, rate, index, and strains were assessed. Disease rate was calculated as a percentage of the number of affected plants against the total plant population. The disease index (DI) was calculated as DI $=[($ Root rot disease grades $\times$ number of infected plants)/ (total checked plants $\times 7$ )] $\times 100$.

\subsection{Statistical analysis}

All data were analyzed using Microsoft Office Excel 2007. A variance analysis (ANOVA) was performed on all data using SPSS 19.0 (IBM) software, and differences between the treatments were calculated using the LSD at the 0.05 probability level. Figures were generated using Origin 9.0 (Origin Lab) software [22].

\subsection{PCR Amplification of 16S And18s Rrna, illumina sequencing and data processing}

This protocol was conducted as provided in detail by Han [22]. In brief, DNA was extracted from soil samples using the E.Z.N.A. ${ }^{\circledR}$ Soil DNA kit (Omega Bio-Tec, Inc., USA) following the manufacturer's guidelines. The PCR was performed for the bacterial $16 \mathrm{~S}$ ribosomal RNA gene with primer sets F: 5'-GCC TTG CCA GCC CGC TCA GTC AGA GTT TGA TCCTGG CTC AG-3'; R: 5'- GCC TCC CTC GCG CCA TCA GNN NNN NNN NNC ATG CTG CCT CCC GTA GGA GT-3' and for the fungus identification with the primer sets F: 5'-GCC TTG CCA GCC CGC TCA GAC GGT ATC T (AG)A TC(AG) TCT TCG-3'; R: 5'-GCC TCC CTC GCG CCA TCA GNN NNN NNN NNN GGC AAG TCT GGT GCC AG-3'. The sequencing of the barcoded amplicons was done using the paired-end method with an Illumina MiSeq (Illumina, San Diego, CA, USA) system through a 6cycle index. Orthogonal Taxonomic Units (OTU) status and identification was achieved by using QIIME software that compared the OTU representative sequence to the template sequence of the corresponding database to get the taxonomic information corresponding to each OUT based on the procedures by DeSantis et al. [23] and Huson et al. [24]. Community diversity was calculated through Simpson indices using QIIME software. The specific composition of each sample at genus level was calculated based on the results on OTU classification and taxonomic status identification.

\subsection{Spearman correlation analysis of microbial diversity and environmental factors}

To further understanding the correlation of microbial diversity and environmental factors such as the content of N, P, K, and the activities of PPO, SC, UE and CAT, the Spearman correlation analysis was carried out as reported previously [25]. 


\section{Results and discussions}

\subsection{Agronomic Traits in Different Crop Rotations}

The agronomic traits markedly increased under the FC condition compared with the CC (Figure 1). The values of leaf area (LA), number of leaves, leaf area index (LAI), plant height, crop productivity, and polysaccharide content under FC treatment significantly higher than CC treatment. Additionally, the values for Chlorophyll-a, Chlorophyll-b, and total chlorophyll content were significantly increased in FC cropping system compared with the CC (Figure 2).

\subsection{Root Rot Disease Index in Different Cropping Systems}

The root rot disease index was affected by different rotation (Figure 3). In this study, there were 89 strains of root rot diseases that were identified across all the cropping systems (CC and FC) at three stages (SS, FS, RE stage). The number of disease cases, disease rate and disease index were significantly lower under FC compared with CC system. During RE stage, the number of disease cases, disease rate and disease index were lower than SS and FS under the CC.

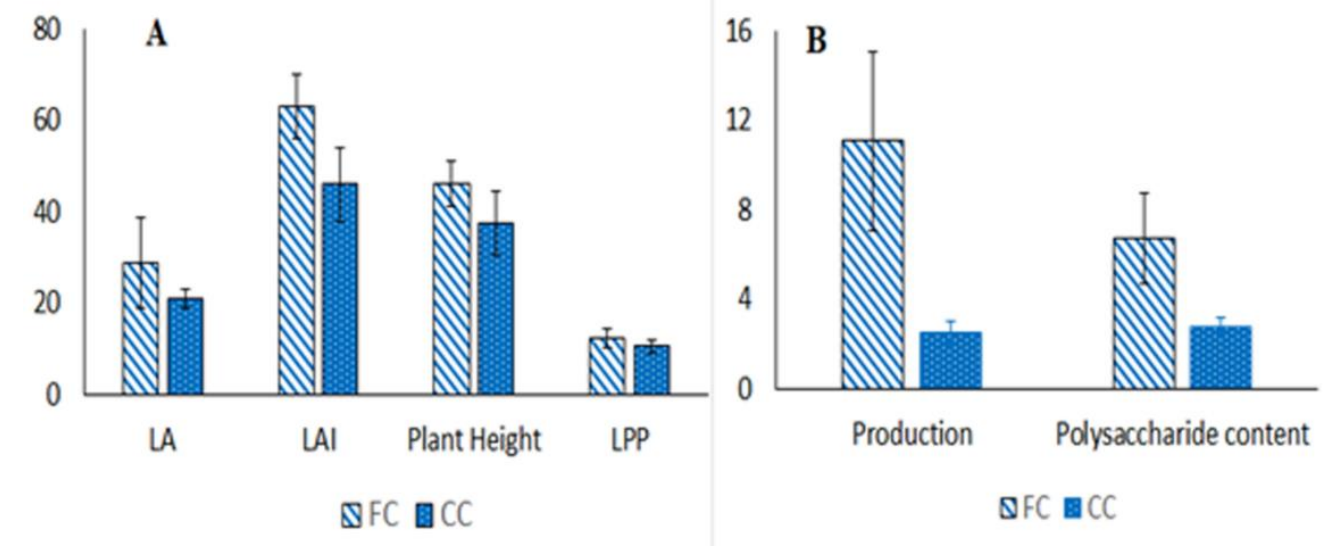

Figure 1. Agronomic traits (A- morphological; B- productivity) of P.odoratum under different cropping systems. FC- First year vegetable, second subsequent year P.odoratum; CC- First year P.odoratum, second subsequent year P.odoratum; LA- average leaf area $\times 10^{-1}\left(\mathrm{~cm}^{2}\right)$, LAI- Leaf area index $\times 10^{-2}$, Average plant height $(\mathrm{cm})$ and LPP-Average number of leaves per plant, Production $\times 10^{-}$ ${ }^{1}(\mathrm{Kg} / \mathrm{m})$, Polysaccharide content $(\%)$

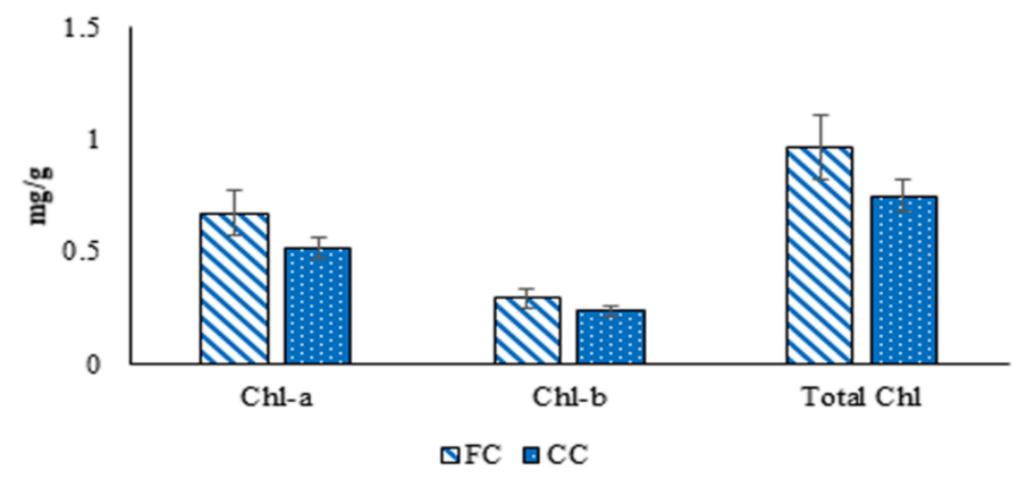

Figure 2. Chlorophyll contents under different cropping systems. Chlorophyll-a (Chl-a), Chlorophyll-b (Chl-b) and total chlorophyll (Total chl); FC- First year vegetable, second subsequent year P.odoratum; CC- First year P.odoratum, second subsequent year P.odoratum 


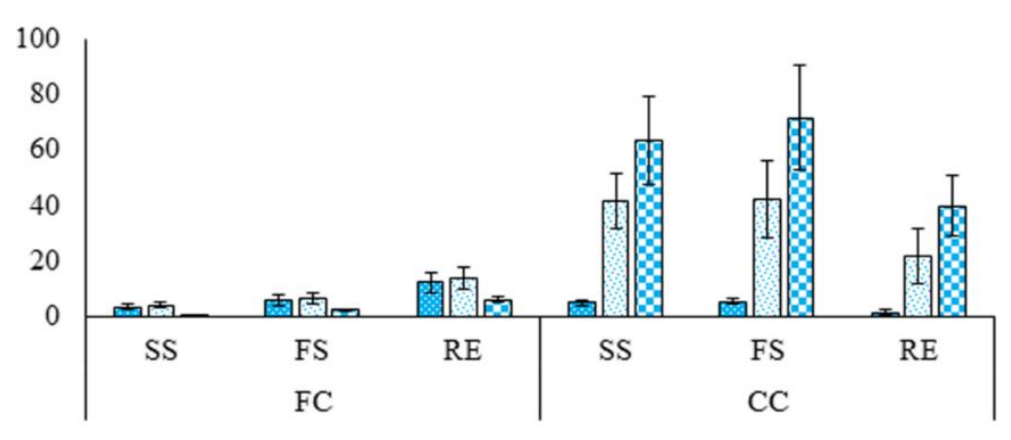

No. of Cases $\square$ Disease rate (\%) 回Disease Index (\%)

Figure 3. Root-rot disease indices under different cropping systems. SS- seedling stage, FS- flowering stage, RE- rhizome extension stage, FC- First year vegetable, second subsequent year P.odoratum; CC- First year P.odoratum, second subsequent year P. doratum(N=6)

\subsection{Soil Properties in different cropping systems}

Soil chemical properties were significant influenced by crop rotations at different grow stages of plant (Table 1). In rhizome enlargement stage, TN content under FC was significantly higher compared with the content reported under CC. The value of AN content showed no significant difference between the FC and CC systems in flowering, and wilting stages. The value of TP and AP under the FC was lower than $\mathrm{CC}$ in all stages. However, the TK and $\mathrm{AK}$ under $\mathrm{CC}$ rotation were significantly lower than FC rotation in all stages, except the before planting one. The value of $\mathrm{pH}$ was significantly decreased under the FC compared with CC during all stages.

\subsection{Soil enzyme activities in different cropping systems}

The activities of soil enzymes were affected by crop rotations systems, the value of enzyme activities was significantly different between FC and CC in all three stages (Table 2).The activities of UE, PPO under the FC rotation system were significantly higher than under the CC system but the CAT and SC activities under CC rotation system were higher compared with those reported under FC rotation system in all stages.

\subsection{Soil Microbial composition and diversity in different cropping systems}

According to $16 \mathrm{~S}$ analysis, orthogonal taxonomic units (OTU) results were analyzed in three crop rotation systems (Figure 4). More than 40,000 sequences that represent about 3000 to 4000 OTU's were generated in each crop rotation system. Upon quality filtering and trimming of all the generated OTU's, high quality sequences were obtained from soil samples representing the three rotation systems. The top ten abundant phyla were Proteobacteria, Acidobacteria, Actininobacteria, Chloroflexi, Gemmatimonadetes, Verrucomicrobia, Planctomycetes, Bacteroidetes, Firmicutes and Latescibacteria under all rotation systems (Figure 5). The phylum Proteobacteria was the most dominant in all crop rotation systems with the average relative abundance of $47.31 \%$. On the other hand, the top ten dominant bacterial genera were Sphingomonas, unidentified Burkholderiaceae, Haliangium, Gemmatimonas, Staphylococcus, Streptomyces, Kitasatospora, Candidatus, Udaeobacter, unidentified Gammaproteo bacteria and Candidatus Solibacter under all cropping systems. Sphingomonas had the highest relative abundance followed by Haliangium under the FC rotation system. However, Haliangium had the highest relative abundance then followed by Sphingomonas under $\mathrm{CC}$ and $\mathrm{CK}$.

The top ten fungal phyla are Ascomycota, Basidiomycota, Mortierellomycota, Glomeromycota, Mucoromycota, Chytridiomycota, Rozellomycota, Kickxellomycota, Blastocladiomycota and Olpidiomycota (Figure 6). The top three were consisted of Ascomycota, Basidiomycota and Mortierellomycota with relative abundance of 33.76, 13.31, and $6.25 \%$. 
The OTU richness, Simpson index, and Shannon index values were significantly different under different cropping systems (Figure 7). The FC rotation system significantly increased OTU richness compared with $\mathrm{CC}$ rotation system (Figure 7A). Simpson index indicated a higher microbial diversity in FC rotation systems than in the CC rotation system (Figure 7B). Moreover, the FC cropping system significantly increased Shannon diversity index compared with CK and CC (Figure 7C).

\subsection{Correlation of microbial and environmental factors}

The Spearman correlation analysis applied for the microbial diversity across different cropping systems and environmental factors uncovered that there are 6 bacteria including Spirochaetes, Elusimicrobia, Nitrospirae, Oxyphotobacteria, Bacteroidetes and Proteobacteria exhibiting positive correlation with the most environmental factors such as AN, AP, TN and TP, UE, CAT and ACP, and other 7 bacteria including Berkelbacteria, Euryarchaeota, Rokubacteria, Latescibacteria, Firmicutes, Chloroflexi and Actinobacteria showed negative correlation with the environmental factors (Figure 8). In the same time, the fungi as Aspergillus, Rhizophagus, Colletotrichum, Paraglomus, Ceratotrichum, Zasmidium, Neocosmospora, Scutellinia, Podospora, Volutella, Fusarium and Polythrincium were positive correlated with environmental factors, while other fungi such as Agaricus, Striaticonidium, Talaromyces, Humicola and Cladorrhinum were negative correlated with environmental factors (Figure 8). In addition, the dominant bacteria and fungi showed opposite effect on soil $\mathrm{pH}$ and other factors.

\subsection{The Increased productivity and agronomic traits under crop rotation system}

Many perennial and annual horticultural crops growth and yield have been restricted when repeatedly planted in the same site over a long period of time [26]. This phenomenon has been referred as replant problem. The mechanisms of replant problem are very complex, and have been considered as including multiple cultural practices, soil conditions and other environmental factors. Previous studies have found the link of long-term continuous cropping systems to many agricultural traits [27]. Leaf area used to measure plant photosynthesis, which was a key factor for agronomic traits. Increased leave area of plants could capture more light in photosynthesis and improved leaf area index, thereby increased crop yield [28]. In this study, leave area and chlorophyll contents significantly increased by FC system (Figures 1\&2). Similarly, the higher plant productivity and percentage of the polysaccharide content in FC system compared with CC system could also be based on the same fact as reported by Xia et al. [29]. The putative mechanism may explain the increase of the productivity reported in P.odoratum under FC system.

\subsection{Reduced crop diseases under FC system}

Previous studies have reported that the continuous cropping system may lead to the accumulated populations of harmful microbes, such pathogenic bacteria, fungi and viruses [16]. Therefore, crop rotation was occasionally applied in control and management of crop diseases. In this study, the number of disease cases, disease rate and disease index were significantly increased under the CC system compared with FC system (Figure 3). The results indicated that crop rotation not only improved the soil quality but also has a significant contribution in control of crop diseases in agriculture. In addition, recently developed novel biocontrol techniques on plant pathogens, like plantgrowth-promoting rhizobacteria (PGPR), can be used in combination with crop rotation practice to control and manage crop diseases. PGPR entails the use of naturally occurring and beneficial soil bacteria that are able to colonize rhizosphere and plant roots, promoting plant growth and defense against certain crop pathogens. This method has been successfully applied in control of plant pathogens in various crops [30], which may explain the mechanism how the rotation cropping system reduce crop disease through improving microbial diversity in soil. 


\subsection{Soil Nutrients improved under FC system}

Soil fertility and agronomic traits were influenced by the soil physicochemical characteristics such as $p \mathrm{H}$, salinity, and the property of cropping system. In the present study, the soil $\mathrm{pH}$ corresponding to FC was higher compared with the soil $\mathrm{pH}$ corresponding to $\mathrm{CC}$ rotation system (Table 1). Studies have affirmed that soil $\mathrm{pH}$ decreased in continuously cropped fields due to the release of protons by root organic anions, as malate, citrate and oxalate. The significant variation in the soil chemical properties across all the cropping systems indicated the effects of agricultural practice on the quality of soil (Table 1). Some studies highlighted the impact of tillage practices on the soil chemical properties [29]. Moreover, the lowest total $\mathrm{N}$ and $\mathrm{P}$ contents were reported in all CK plots in different stages, while in FC and CC systems they increased. The physicochemical properties of soil fertility in cropped fields were improved in cultivated lands compared with barren land. This result may be explained by the assumption that crop stimulate microbial activities by shading-off harsh environmental conditions such as solar radiation, thereby increased decomposing plant organic content. Studies show that continuous cropping has a negative contribution to soil chemical traits and nutrient quality compared to rotational cropping system. The present results showed that FC significantly increased the content of TN, AN, TK, AK in soil, compared with CC system (Table 1), which suggests that FC system may improve soil physicochemical characteristics, and enhance nutrient content [31-38].

Table 1. Soil chemical properties in different developmental stages for two cropping systems

\begin{tabular}{|c|c|c|c|c|c|c|c|c|}
\hline $\begin{array}{l}\text { Developmental } \\
\text { stages }\end{array}$ & $\begin{array}{l}\text { Cropping } \\
\text { system }\end{array}$ & $\begin{array}{l}\text { Total } \\
\text { Nitrogen }(\%)\end{array}$ & $\begin{array}{l}\text { Total } \\
\text { Phosphorus } \\
\left(\text { g.kg }^{-1}\right)\end{array}$ & $\begin{array}{l}\text { Total Potassium } \\
\left(\mathrm{mg.g} \mathbf{g}^{-1} \text { of dry }\right. \\
\text { weight })\end{array}$ & $\begin{array}{l}\text { Available } \\
\text { Nitrogen } \\
\left(\mathbf{m g}^{\left.-k^{-1}\right)}\right.\end{array}$ & $\begin{array}{l}\text { Available } \\
\text { Phosphorus } \\
\left(\text { mg.kg }^{-1}\right)\end{array}$ & $\begin{array}{l}\text { Available } \\
\text { Potassium } \\
\left(\text { mg.kg }^{-1}\right)\end{array}$ & pH \\
\hline \multirow{3}{*}{ Before planting } & $\mathrm{FC}$ & $0.19 \pm 0.004 \mathrm{~A}$ & $0.20 \pm 0.006 \mathrm{~A}$ & $13.34 \pm 0.14 \mathrm{~B}$ & $93.6 \pm 1.0 \mathrm{~A}$ & $160.9 \pm 3.1 \mathrm{~B}$ & $30.8 \pm 1.1 \mathrm{~B}$ & $5.28 \pm 0.02 \mathrm{~B}$ \\
\hline & $\mathrm{CC}$ & $0.17 \pm 0.004 \mathrm{~B}$ & $0.20 \pm 0.002 \mathrm{~A}$ & $15.92 \pm 1.36 \mathrm{~A}$ & $84.2 \pm 1.0 \mathrm{~B}$ & $191.1 \pm 3.4 \mathrm{~A}$ & $27.2 \pm 0.7 \mathrm{C}$ & $4.98 \pm 0.04 \mathrm{C}$ \\
\hline & $\mathrm{CK}$ & $0.14 \pm 0.002 \mathrm{C}$ & $0.18 \pm 0.013 \mathrm{~A}$ & $13.23 \pm 0.18 \mathrm{~B}$ & $66.7 \pm 1.0 \mathrm{C}$ & $113.9 \pm 4.0 \mathrm{C}$ & $37.6 \pm 0.6 \mathrm{~A}$ & $5.52 \pm 0.05 \mathrm{~A}$ \\
\hline \multirow{3}{*}{ Flowering stage } & $\mathrm{FC}$ & $0.19 \pm 0.030 \mathrm{~A}$ & $0.22 \pm 0.015 \mathrm{~A}$ & $16.07 \pm 1.27 \mathrm{~A}$ & $91.5 \pm 0.9 \mathrm{~A}$ & $161.4 \pm 4.4 \mathrm{~B}$ & $34.0 \pm 2.0 \mathrm{~A}$ & $5.58 \pm 0.48 \mathrm{~A}$ \\
\hline & $\mathrm{CC}$ & $0.20 \pm 0.003 \mathrm{~A}$ & $0.23 \pm 0.015 \mathrm{~A}$ & $13.64 \pm 0.10 \mathrm{AB}$ & $83.7 \pm 3.0 \mathrm{~B}$ & $259.1 \pm 2.7 \mathrm{~A}$ & $34.7 \pm 1.9 \mathrm{~A}$ & $5.56 \pm 0.41 \mathrm{~A}$ \\
\hline & $\mathrm{CK}$ & $0.18 \pm 0.003 \mathrm{~A}$ & $0.16 \pm 0.003 \mathrm{~B}$ & $13.19 \pm 0.71 \mathrm{~B}$ & $68.5 \pm 2.0 \mathrm{C}$ & $90.9 \pm 4.2 \mathrm{C}$ & $28.4 \pm 0.8 \mathrm{~B}$ & $5.49 \pm 0.04 \mathrm{~A}$ \\
\hline \multirow{3}{*}{$\begin{array}{l}\text { Rhizome } \\
\text { enlargement }\end{array}$} & $\mathrm{FC}$ & $0.20 \pm 0.001 \mathrm{~A}$ & $0.24 \pm 0.006 \mathrm{~A}$ & $15.83 \pm 0.93 \mathrm{~A}$ & $93.6 \pm 1.0 \mathrm{~A}$ & $152.2 \pm 6.8 \mathrm{~B}$ & $25.5 \pm 0.7 \mathrm{~B}$ & $5.38 \pm 0.28 \mathrm{~B}$ \\
\hline & $\mathrm{CC}$ & $0.18 \pm 0.001 \mathrm{~B}$ & $0.20 \pm 0.009 \mathrm{~B}$ & $14.51 \pm 1.31 \mathrm{~A}$ & $86.6 \pm 1.0 \mathrm{~B}$ & $198.1 \pm 3.6 \mathrm{~A}$ & $33.3 \pm 1.3 \mathrm{~A}$ & $5.24 \pm 0.05 \mathrm{~B}$ \\
\hline & $\mathrm{CK}$ & $0.13 \pm 0.001 \mathrm{C}$ & $0.11 \pm 0.004 \mathrm{C}$ & $13.25 \pm 0.36 \mathrm{~A}$ & $52.7 \pm 1.0 \mathrm{C}$ & $52.1 \pm 1.5 \mathrm{C}$ & $27.0 \pm 0.6 \mathrm{~B}$ & $6.31 \pm 0.26 \mathrm{~A}$ \\
\hline \multirow{3}{*}{ Wilting stage } & $\mathrm{FC}$ & $0.19 \pm 0.017 \mathrm{~A}$ & $0.21 \pm 0.007 \mathrm{~B}$ & $15.59 \pm 0.33 \mathrm{~B}$ & $72.0 \pm 2.0 \mathrm{~A}$ & $144.5 \pm 9.9 \mathrm{~B}$ & $22.5 \pm 1.5 \mathrm{~A}$ & $5.32 \pm 0.14 \mathrm{~B}$ \\
\hline & $\mathrm{CC}$ & $0.20 \pm 0.005 \mathrm{~A}$ & $0.30 \pm 0.015 \mathrm{~A}$ & $11.74 \pm 0.24 \mathrm{C}$ & $69.7 \pm 3.0 \mathrm{~A}$ & $225.6 \pm 5.2 \mathrm{~A}$ & $25.1 \pm 2.0 \mathrm{~A}$ & $5.16 \pm 0.31 \mathrm{~B}$ \\
\hline & $\mathrm{CK}$ & $0.15 \pm 0.005 \mathrm{~B}$ & $0.16 \pm 0.012 \mathrm{C}$ & $16.88 \pm 0.51 \mathrm{~A}$ & $45.7 \pm 1.0 \mathrm{~B}$ & $58.5 \pm 1.6 \mathrm{C}$ & $22.1 \pm 2.0 \mathrm{~A}$ & $6.21 \pm 0.04 \mathrm{~A}$ \\
\hline
\end{tabular}

Mean \pm standard error, FC- First year vegetable, second subsequent year P.odoratum; CC- First year P. odoratum, second subsequent year P.odoratum; CK- No crop planted in the first and second subsequent year; N- Nitrogen; P- Phosphorus; K- Potassium. Where ANOVA was significant, LSD was used as post hoc test and represented by different uppercase letters within each raw per developmental stage $(\mathrm{N}=12$ and $\mathrm{P}<0.05)$.

\subsection{Enzyme activities promoted under FC system}

Soil enzymes usually derived from soil microorganisms, plants and animals play a key role in various soil biochemical processes and decomposition of soil organic matter [21]. Enzyme activities influence the cycling of nitrogen, phosphor usually utilized to evaluate the health of soil. Soil enzymes are the best indicators for microbial activities because they are sensitive to any disruption or alteration in the soil structure or microbial community [36]. Thus, the enzyme activities with significant changes at different stages of crop may be driven by the microbial activities because the bacterial functions were related to various enzymatic activities (Table 2). This is consistent with some studies showing that crop rotation significantly regulated soil microbial activities, hence affected soil enzymatic 
activities [37]. In this study, the activities of UE, CAT, ACP and PPO significantly increased under FC system compared with CK. These results may be due to the changes in the soil organic matter, and the adaptation and proliferation of soil microbes in FC systems. However, the enzyme activities at flowering stage were significantly higher than other growth stages among FC and CC systems, which suggested the highest microbial activities at the FS. The activities of UE, PPO and ACP dominantly decreased under $\mathrm{CC}$ system compared to FC system. These results suggested that FC promotes microbial activities that mediate $\mathrm{N}$ and $\mathrm{P}$ cycle in the soil, which may drive nutrient (e.g., $\mathrm{N}$ and $\mathrm{P}$ ) cycle, thus increasing nutrient availability to crops.

Table 2. Enzymatic activities within the cropping systems and across the developmental stages.

\begin{tabular}{|c|c|c|c|c|c|c|}
\hline Period & $\begin{array}{l}\text { Cropping } \\
\text { system }\end{array}$ & $\begin{array}{c}\text { Urease activity } \\
\left(\mathrm{mg}^{-\mathrm{g}^{-1}}\right)\end{array}$ & $\begin{array}{l}\text { Polyphenol oxidase } \\
\text { activity }\left(\mathrm{mg}^{-\mathrm{g}^{-1}}\right)\end{array}$ & $\begin{array}{c}\text { Catalase activity } \\
\left(\mathrm{mg}^{\left.-\mathrm{g}^{-1}\right)}\right.\end{array}$ & $\begin{array}{c}\text { Sucrase } \\
\text { activity }\left(\mathrm{mg}^{-g^{-1}} \cdot \mathrm{h}^{-1}\right)\end{array}$ & $\begin{array}{l}\text { Phosphatase } \\
\text { activity } \\
\left(\text { nmol.g-1 }^{-1} \cdot \mathbf{h}^{-1}\right)\end{array}$ \\
\hline \multirow{3}{*}{ Before planting } & $\mathrm{FC}$ & $381.14 \pm 16.78 \mathrm{~A}$ & $51.00 \pm 0.82 \mathrm{AB}$ & $10.78 \pm 0.75 \mathrm{~A}$ & $12.29 \pm 0.08 \mathrm{~B}$ & $22.91 \pm 0.63 \mathrm{~A}$ \\
\hline & $\mathrm{CC}$ & $378.07 \pm 9.69 \mathrm{~A}$ & $49.22 \pm 0.50 \mathrm{~B}$ & $11.53 \pm 0.10 \mathrm{~A}$ & $12.90 \pm 0.26 \mathrm{~B}$ & $22.86 \pm 1.26 \mathrm{~A}$ \\
\hline & $\mathrm{CK}$ & $226.45 \pm 11.06 \mathrm{~B}$ & $52.46 \pm 0.93 \mathrm{~A}$ & $5.92 \pm 0.63 \mathrm{~B}$ & $16.37 \pm 0.24 \mathrm{~A}$ & $13.38 \pm 0.25 \mathrm{~B}$ \\
\hline \multirow{3}{*}{ Flowering stage } & $\mathrm{FC}$ & $586.2 \pm 26.3 \mathrm{~A}$ & $57.9 \pm 0.9 \mathrm{~A}$ & $16.2 \pm 1.0 \mathrm{~A}$ & $17.0 \pm 0.1 \mathrm{C}$ & $28.0 \pm 0.1 \mathrm{~A}$ \\
\hline & $\mathrm{CC}$ & $392.1 \pm 32.2 \mathrm{~B}$ & $49.3 \pm 0.8 \mathrm{~B}$ & $17.9 \pm 1.0 \mathrm{~A}$ & $22.6 \pm 0.2 \mathrm{~A}$ & $22.9 \pm 0.8 \mathrm{~B}$ \\
\hline & $\mathrm{CK}$ & $380.3 \pm 42.1 \mathrm{~B}$ & $50.2 \pm 1.5 \mathrm{~B}$ & $9.8 \pm 0.6 \mathrm{~B}$ & $20.0 \pm 0.4 \mathrm{~B}$ & $22.0 \pm 0.6 \mathrm{~B}$ \\
\hline \multirow{3}{*}{$\begin{array}{l}\text { Rhizome } \\
\text { enlargement }\end{array}$} & $\mathrm{FC}$ & $477.3 \pm 23.2 \mathrm{~A}$ & $48.3 \pm 0.9 \mathrm{~A}$ & $19.5 \pm 1.0 \mathrm{~A}$ & $18.4 \pm 0.3 \mathrm{~A}$ & $24.0 \pm 1.0 \mathrm{~A}$ \\
\hline & $\mathrm{CC}$ & $288.6 \pm 17.1 \mathrm{~B}$ & $45.6 \pm 0.4 \mathrm{~B}$ & $17.0 \pm 0.2 \mathrm{~B}$ & $11.2 \pm 0.2 \mathrm{C}$ & $19.7 \pm 0.4 \mathrm{~B}$ \\
\hline & $\mathrm{CK}$ & $156.3 \pm 5.4 \mathrm{C}$ & $49.6 \pm 0.5 \mathrm{~A}$ & $14.2 \pm 0.5 \mathrm{C}$ & $15.8 \pm 0.1 \mathrm{~B}$ & $12.9 \pm 0.4 \mathrm{C}$ \\
\hline \multirow{3}{*}{ Wilting stage } & $\mathrm{FC}$ & $394.4 \pm 38.2 \mathrm{~A}$ & $49.3 \pm 0.3 \mathrm{~A}$ & $15.7 \pm 1.0 \mathrm{AB}$ & $14.6 \pm 0.2 \mathrm{C}$ & $23.9 \pm 0.5 \mathrm{~A}$ \\
\hline & $\mathrm{CC}$ & $298.2 \pm 25.7 \mathrm{~B}$ & $47.7 \pm 1.2 \mathrm{~A}$ & $17.3 \pm 1.0 \mathrm{~A}$ & $20.8 \pm 0.2 \mathrm{~A}$ & $22.0 \pm 0.3 \mathrm{~B}$ \\
\hline & $\mathrm{CK}$ & $289.7 \pm 7.8 \mathrm{~B}$ & $39.3 \pm 1.3 \mathrm{~B}$ & $13.8 \pm 1.1 \mathrm{~B}$ & $20.2 \pm 0.2 \mathrm{~B}$ & $15.5 \pm 0.3 \mathrm{C}$ \\
\hline
\end{tabular}

Mean \pm standard error, FC- First year vegetable, second subsequent year P.odoratum; CC- First year P. odoratum, second subsequent year P.odoratum;CK- No crop planted in the first and second subsequent year; Where ANOVA was significant, LSD was used as post hoc test and represented in different uppercase letters within each column, $\mathrm{N}=12$ and $\mathrm{P}<0.05$.

\subsection{Benefit of plants as result of changes in soil microbial community composition under FC}

Increased plant diversity has been shown to improve bacterial abundance of soil ecosystem and further reduce negative feedback. Planting of perennial crops has similarly been shown to have a lesser diversity compared to growth of seasonal crops in a rotational systems. In this study, lower OTUs were observed in the CC compared with FC system (Figure 4). Further, the relative bacterial abundance and diversity were also lower in $\mathrm{CC}$ system than in FC system (Figure 7). The results suggested that soil microbial diversity was higher under the FC system than under the CC system. This is consistent with the result we reported concerning the enzyme activities and soil nutrients under the CC system lower than the FC cropping system. The studies illustrated that highly diverse cropping systems were less affected by soil-borne pathogens than the plant mono-fields or low-diversity fields. This is consistent with the results of crop diseases (Figure 3), and highlighted that FC system not only increased soil bacterial relative abundance but also decreased soil borne pathogens [25-28].

Sphingomonas have been reported to be capable of metabolical versatility, and to play a role in the degradation of various compounds, including some environmental contaminants, which harms the plants. The relative abundance of Sphingomonas increased under FC cropping system, and this indicated that FC system showed potential for degrading soil contaminants, improving soil environment and promoting plant growth. Haliangium was obligate halophile, and requires a saline 
environment. The relative abundance of Haliangium decreased when CC system was practiced, suggesting that $\mathrm{CC}$ system affected the abundance of some bacteria because of the decreased soil $\mathrm{pH}$ (Table 1).This is consistent with some studies that uncovered the relatively high acidity conditions within the soils under a rotational system [30].

Previous studies demonstrated that some fungi such as Podospora, Furasium, Neocosmospora and Ceratobasidium, and some bacteria such as Proteobacteria, Bacteroidetes and Nitrospirae may lead to the higher occurrence of plant diseases and replant problem. In this study, the Spearman correlation analysis showed the close and positive relationship between these fungi together with bacteria and the environmental factors including AN, AP, TN and TP, UE, CAT and ACP (Figure 8). These factors may be associated with replant problem under CC system (Table 2), which suggests the possible negative effects of microbial diversity on the environmental factors under CC system [39-42].

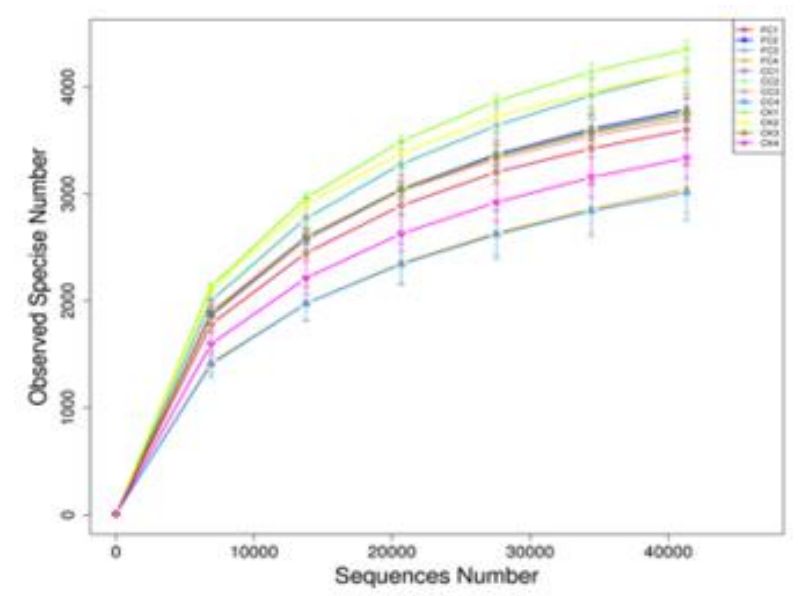

Figure 4. Distribution of orthogonal taxonomic units across the cropping systems. FC- First year vegetable, second subsequent year P.odoratum; CC-

First year P.odoratum, second subsequent year P.odoratum; CK- No crop planted in the first and second subsequent year

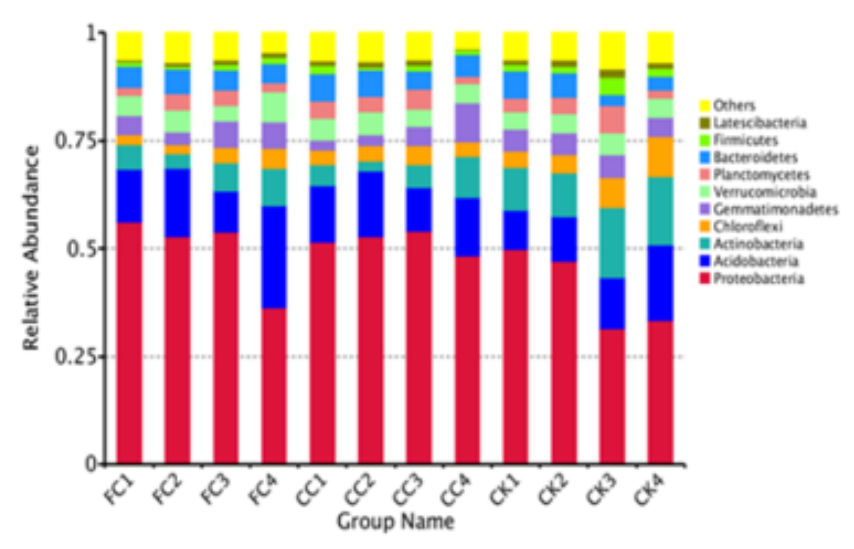

Figure 5. Relative abundance of top ten dominant bacterial phyla across the cropping systems. FC- First year vegetable, second subsequent year P.odoratum;

CC- First year P.odoratum, second subsequent year P.odoratum; CK- No crop planted in the first and second subsequent year

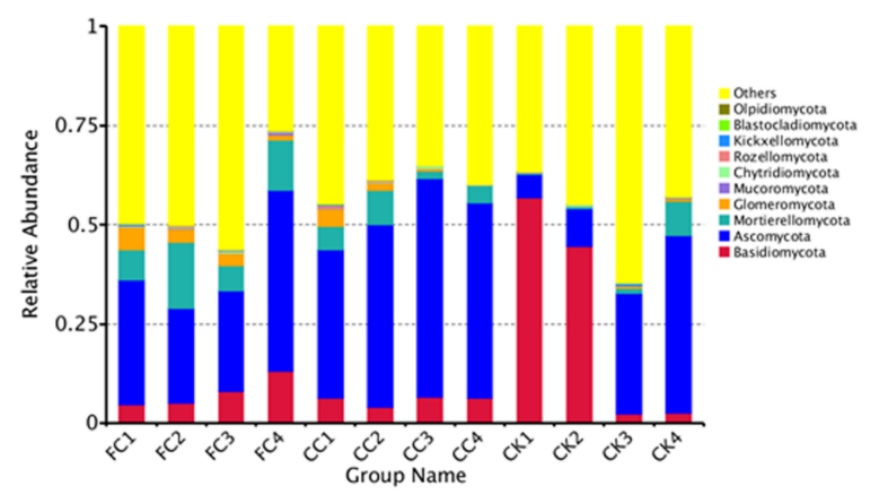

Figure 6. Relative abundance of top ten dominant fungal phyla across the cropping systems. 
FC, First year vegetable, second subsequent year P.odoratum; CC, the First year P.odoratum, second subsequent year P.odoratum; CK, no crop planted in the first and second subsequent year
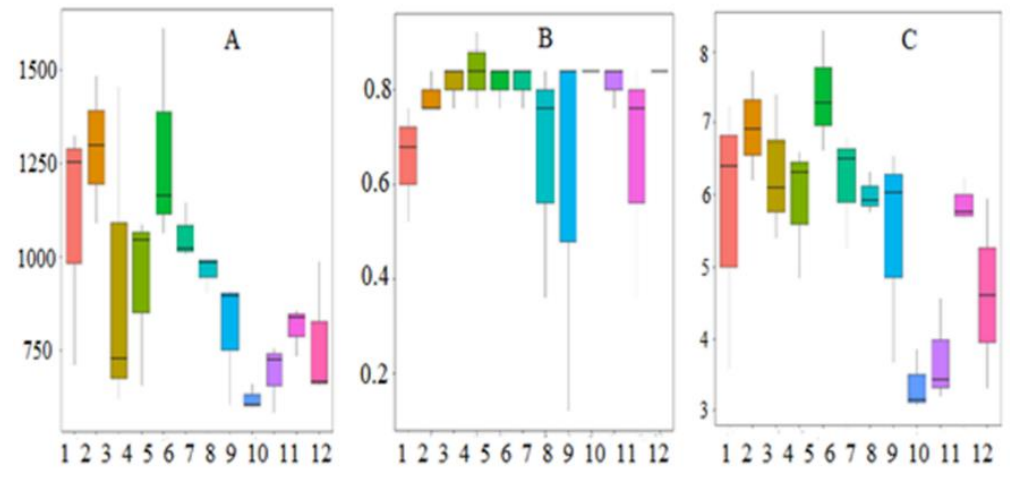

Figure 7. Box whisker plots showing mean values for bacteria alpha diversity. (A) OTU richness and $\alpha$-diversity indices (B) Simpson index plot, (C) Shannon index across the cropping systems (FC1, FC2, FC3 and FC4 for plots 1-4; CC1, CC2, CC3 and CC4 for plots 5-8; CK1, CK2, CK3 and CK4 for plots 9-12)

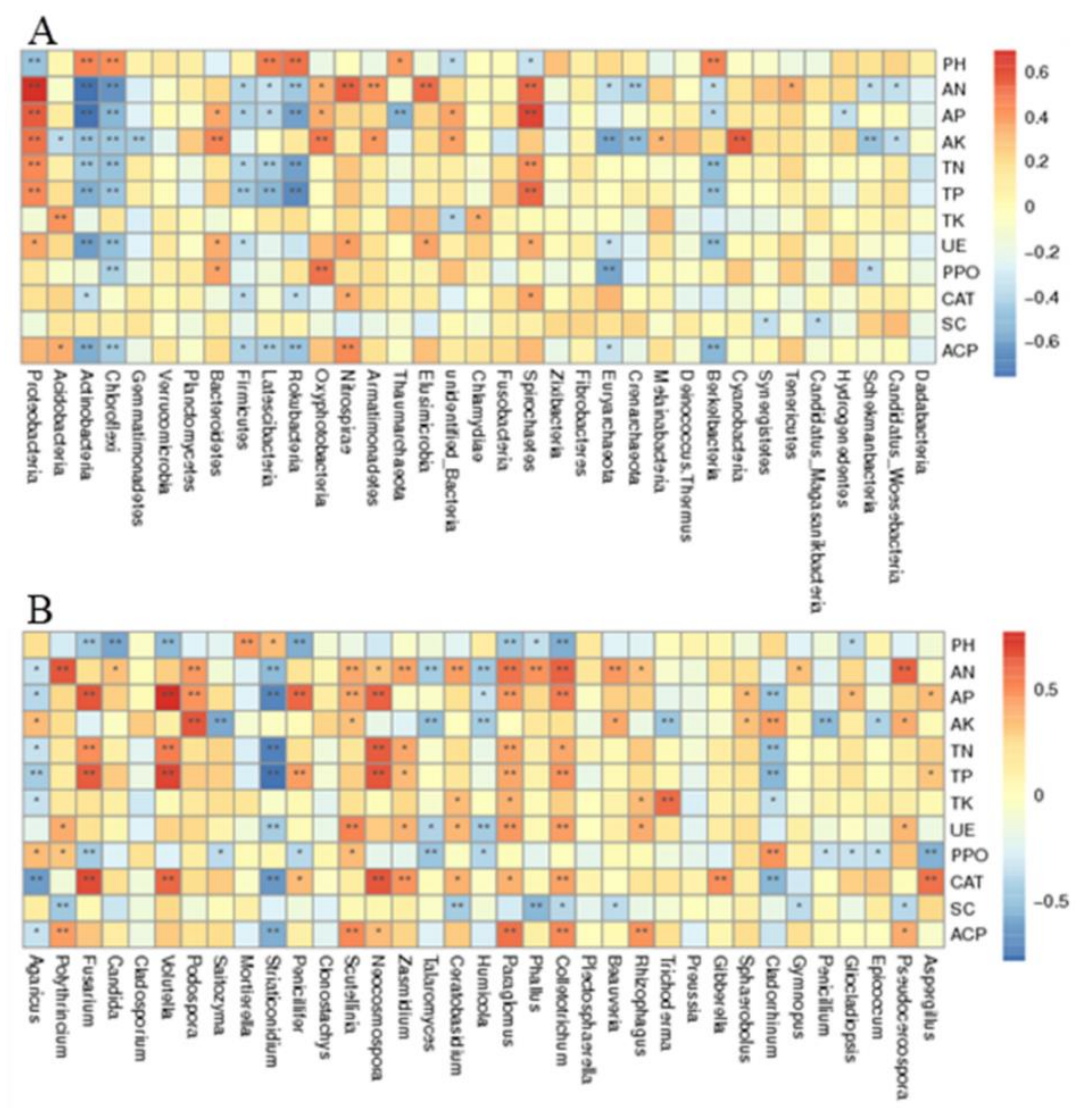

Figure 8. Correlation of the microbial diversity and environmental factors. (A) bacterial and environmental factors, (B) fungal and environmental factors. $\mathrm{PH}, \mathrm{pH}$; $\mathrm{AN}$, available $\mathrm{N}$; $\mathrm{AP}$, available

P; AK, available K; TN, total N; TP, total P; TK, total K; UE, Urease; PPO, Polyphenol Oxidase; CAT, Catalase; SC, Sucrase; ACP, Acid Phosphatase. * represents significant difference at $p<0.05, * *$ for highly significant difference at $\mathrm{P}<0.01$

\section{Conclusions}

In summary, the present results suggested that the FC system improved productivity and other agronomic traits of P.odoratum compared with CC system, and revealed the underlying mechanisms 
and found that FC promoted soil nutrient content, reduced root rot diseases, improved enzyme activity, shifted bacterial community composition toward groups with high environmental contaminants degradation ability, and increased microbial diversity, thereby improved productivity. According to the results of this study, vegetable-P.odoratum rotation system is recommended in cultivation of P.odoratum.

Acknowledgement: We are grateful to the Scientific Research Project of Public Welfare Industry (Agriculture) (201503123-05), Collaborative Innovation Center for Field Weeds Control in Hunan Province and the construct program of the applied and characteristic discipline in Hunan province for funding this study.

\section{References}

1. ZHAO, P., ZHAO, C., LI, X., GAO, Q., HUANG, L., XIAO, P., GAO, W., The genus Polygonatum: A review of ethnopharmacology, phytochemistry and pharmacology. $J$ Ethnopharmacol., 214, 2018, 274-291.

2. WANG, D., ZENG, L., LI, D., PU, W., Antioxidant activities of different extracts and homoisoflavanones isolated from the Polygonatum odoratum. Nat. Prod. Res., 27, 2013, 1111-1114.

3. TAI, Y., SUN, Y.M., ZOU, X., PAN, Q., LAN, Y. D., HUO, Q., ZHU, J.W., GUO, F., ZHENG, C.Q., WU, C. Z., LIU, H., Effect of Polygonatum odoratum extract on human breast cancer MDAMB-231 cell proliferation and apoptosis. Exp. Ther. Med., 12, 2016, 2681-2687.

4. BAI, H., LIU, R., CHEN, H. L., ZHANG, W., WANG, X., ZHANG, X.D., HAI, C.X., Enhanced antioxidant effect of caffeic acid phenethyl ester and Trolox in combination against radiation inducedoxidative stress. Chem. Biol. Interact., 207, 2014, 7-15.

6. SHU, X.S., LV, J. H., TAO, J., LI, G. M., LI, H.D., MA, N., Antihyperglycemic effects of total flavonoids from Polygonatum odoratum in STZ and alloxan-induced diabetic rats. J. Ethnopharmacol., 124, 2009, 539-543.

7. SERVILI, M., SELVAGGINI, R., TATICCHI, A., ESPOSTO, S., MONTEDORO, G., Volatile compounds and phenolic composition of virgin olive oil: optimization of temperature and time of exposure of olive pastes to air contact during the mechanical extraction process. J. Agric. Food. Chem., 51, 2003, 7980-7988.

8. DENG, Y., HE, K., YE, X., CHEN, X., HUANG, J., LI, X., YUAN, L., JIN, Y., JIN, Q., LI, P., Saponin rich fractions from Polygonatum odoratum (Mill.) Druce with more potential hypoglycemic effects. J. Ethnopharmacol., 141, 2012, 228-233.

9. LIU, X., ZHANG, M., GUO, K., JIA, A., SHI, Y., GAO, G., SUN, Z., LIU, C., Cellulase-assisted extraction, characterization, and bioactivity of polysaccharides from Polygonatum odoratum. Int. J. Biol. Macromol., 75, 2015, 258-265.

10. FRENZEL, E., KRANZLER, M., STARK, T.D., HOFMANN, T., EHLING-SCHULZ, M., The Endospore-Forming Pathogen Bacillus cereus Exploits a Small Colony Variant-Based Diversification Strategy in Response to Aminoglycoside Exposure. MBio., 6, 2015, 01172-01115.

11. SUN, Y., SUN, G., XU, Y., WANG, L., LIANG, X., LIN, D., HU, F., Assessment of natural sepiolite on cadmium stabilization, microbial communities, and enzyme activities in acidic soil. Environ. Sci. Pollut. Res. Int., 20, 2013, 3290-3299.

12. ZHANG, W., ZHANG, G., LIU, G., DONG, Z., CHEN, T., ZHANG, M., AN, L., An, Bacterial diversity and distribution in the southeast edge of the Tengger Desert and their correlation with soil enzyme activities. J. Environ. Sci., 24, 2012, 2004-2011.

13. TILMAN, D., CASSMAN, K. G., MATSON, P.A., NAYLOR, R., POLASKY, S., Agricultural sustainability and intensive production practices. Nature., 418, 2002, 671-677.

14. CHUNG, Y.A., JUMPPONEN, A., RUDGERS, J.A., Divergence in Diversity and Composition of Root-Associated Fungi Between Greenhouse and Field Studies in a Semiarid Grassland. Microb. Ecol., 78, 2019, 122-135. 
15. LI, X., LEWIS, E.E., LIU, Q., LI, H., BAI, C., WANG, Y., Effects of long-term continuous cropping on soil nematode community and soil condition associated with replant problem in strawberry habitat. Sci. Rep., 6, 2016, 30466.

16. MULVANEY, R.L., KHAN, S.A., ELLSWORTH, T.R., Synthetic nitrogen fertilizers deplete soil nitrogen: a global dilemma for sustainable cereal production. J. Environ. Qual., 38, 2009, 2295-2314.

17. YANG, Y., ZHOU, X., TIE, B., PENG, L., LI, H., WANG, K., ZENG, Q., Comparison of three types of oil crop rotation systems for effective use and remediation of heavy metal contaminated agricultural soil. Chemosphere., 188, 2017, 148-156.

18. BARBIERI, P., PELlERIN, S., NESME, T., Comparing crop rotations between organic and conventional farming. Sci. Rep., 7, 2017, 13761.

19. WANG, E., HARMAN, W.L., WILLIAMS, J.R., XU, C., Simulated effects of crop rotations and residue management on wind erosion in Wuchuan, west-central Inner Mongolia, China. J. Environ. Qual., 31, 2002, 1240-1247.

20. HAN, G., LAN, J., CHEN, Q., YU, C., BIE, S., Response of soil microbial community to application of biochar in cotton soils with different continuous cropping years. Sci. Rep., 7, 2017, 10184.

21. HUSON, D.H., MITRA, S., RUSCHEWEYH, H.J., WEBER, N., SCHUSTER, S.C., Integrative analysis of environmental sequences using MEGAN4. Genome. Res., 21, 2011, 1552-1560.

22. Azen, R.D., SASS, A., Comparing the squared multiple correlation coefficients of non-nested models: an examination of confidence intervals and hypothesis testing. Br. J. Math. Stat. Psychol., 61, 2008, 163-178.

23. YIM, B., NITT, H., WREDE, A., JACQUIOD, S., SØRENSEN, S.J., WINKELMANN, T., SMALLA, K., Effects of Soil Pre-Treatment with Basamid(R) Granules, Brassica juncea, Raphanus sativus, and Tagetes patula on Bacterial and Fungal Communities at Two Apple Replant Disease Sites. Front. Microbiol., 8, 2017, 1604.

24. ABDELKRIM, S., JEBARA, S.H., JEBARA, M., Antioxidant systems responses and the compatible solutes as contributing factors to lead accumulation and tolerance in Lathyrus sativus inoculated by plant growth promoting rhizobacteria. Ecotoxicol. Environ. Saf., 166, 2018, 427-436.

25. HAHM, M. S., SON, J. S., KIM, B. S., GHIM, S. Y., Comparative study of rhizobacterial communities in pepper greenhouses and examination of the effects of salt accumulation under different cropping systems. Arch. Microbiol., 199, 2017, 303-315.

26. WANG, Y., DOU, S., ZHANG, Q., EBADI, A. G., CHEN, J., TOUGHANI, M., Bacterial Separation and Community Diversity Analysis of Petroleum Contaminated Soil in Yumen Oilfield. Rev. Chim.,71(3), 2020, 595-607.

27. YANG1, M., EFEHI, N., JIN, Y., ZHANG, Q., EBADI, A. G., TOUGHANI, M., Hot Water Extraction of Crude Polysaccharide from Codonopsis pilosula and Determination of the Rheological Properties. Rev. Chim., 71(5), 2020, 441-449.

28. YANG, M., MERCY, A. O., EFEHI, N., VENERA, M., LIU, X., EBADI, A. G., TOUGHANI, M., Evaluation of Physicochemical and DPPH. Cleaning Activity of Ultrasonic Assisted Extraction of Polysaccharide from Leonurus japonicas. Rev. Chim., 71(4), 2020, 601-614.

29. LIANG, H., KHAN, Z. I., AHMAD, K., NISAR, A., MAHMOOD, Q., EBADI, A. G., TOUGHANI, M., Assessment of Zinc and Nickel Profile of Vegetables Grown in Soil Irrigated with Sewage Water. Rev. Chim., 71(4), 2020, 500-511.

30. EBADI, A. G., TOUGHANI, M., NAJAFI, A., BABAEE, M., A brief overview on current environmental issues in Iran. Cent. Asian. J. Environ. Sci. Technol. Innov., 1(1), 2020, 1-11.

31. USMAN, A. K., ABDULlAHI, A. H., A OPARA, J., Forest resources management using geospatial tools (Case study: Northern Nigeria). Cent. Asian. J. Environ. Sci. Technol. Innov., 1(1), 2020, 12-20.

32. QAYYUM S., KHAN I., MENG K., ZHAO Y., PENG C., A review on remediation technologies for heavy metals contaminated soil. Cent. Asian. J. Environ. Sci. Technol. Innov., 1(1), 2020, 21-29. 
33. NNAEMEKA A. N., Environmental pollution and associated health hazards to host communities (Case study: Niger delta region of Nigeria). Cent. Asian. J. Environ. Sci. Technol. Innov., 1(1), 2020, 30-42.

34. GERKE, J., Phytate (Inositol Hexakisphosphate) in Soil and Phosphate Acquisition from Inositol Phosphates by Higher Plants. A Review. Plants., 4, 2015, 253-266.

35. D'ACUNTO, L., ANDRADE, J. F., POGGIO, S. L., SEMMARTIN, M., Semmartin, Diversifying crop rotation increased metabolic soil diversity and activity of the microbial community. Agric. Ecosyst. Environ., 257, 2018, 159-164.

36. MARTYNIUK, S., PIKULA, D., KOZIEL, M., Soil properties and productivity in two long-term crop rotations differing with respect to organic matter management on an Albic Luvisol. Sci. Rep., 9, 2019, 1878.

37. BEYER, L., Soil Organic Matter Composition of Spodic Horizons in Podzols of the Northwest German Lower Plain. Sci. Total. Environ., 181, 1996, 167-180.

38. MARON, J. L., MARLER, M., KLIRONOMOS, J. N., ClEVELAND, C. C., Soil fungal pathogens and the relationship between plant diversity and productivity. Ecol. Lett., 14, 2011, 36-41.

39. QUAN, S., RU, C., NAI-PING, S., QING-FENG, W., RUI, W., Change trends of soil nutrients, enzyme activities, and microbial composition in continuous potato cropping system in semi-arid and cool hilly area of Ningxia. J. Soil Water Conserv., 24(6), 2010, 208-212.

40.ACOSTA-MARTÍNEZ, V., ACOSTA-MERCADO, D., SOTOMAYOR-RAMÍREZ, D., \& CRUZRODRÍGUEZ, L., Microbial communities and enzymatic activities under different management in semiarid soils. Appl. Soil Ecol., 38(3), 2008, 249-260.

41. YANG, M., ABDALRAHMAN, H., SONIA, U., MOHAMMED, A. I., VESTINE, U., WANG, M., EBADI, A. G., TOUGHANI, M., The application of DNA molecular markers in the study of Codonopsis species genetic variation, a review. Cell. Mol. Biol., 66(2), 2020, 23-30.

42. Bowles, T. M., Acosta-Martínez, V., Calderón, F., Jackson, L. E. (2014). Soil enzyme activities, microbial communities, and carbon and nitrogen availability in organic agroecosystems across an intensively-managed agricultural landscape. Soil Biol. Biochem., 68, 2014, 252-262.

Manuscript received: 17.03 .2020 